\title{
SYSTEMATICS, TAPHONOMY, AND PALEOECOLOGY OF HOMALONOTID TRILOBITES (PHACOPIDA) FROM THE PONTA GROSSA FORMATION (DEVONIAN), PARANÁ BASIN, BRAZIL
}

\author{
MARCELLO GUIMARÃES SIMÕES \\ Departamento Zoologia, IB, UNESP, Rubião Júnior, Cx.P.510, 18618-000, Botucatu, SP, Brazil. btsimoes@ibb.unesp.br \\ JULIANA DE MORAES LEME \\ Departamento Geologia Sedimentar e Ambiental, IGc, USP, Rua do Lago, 562, 05508-080, São Paulo, SP, Brazil. \\ leme@usp.br \\ SABRINA PEREIRA SOARES \\ Rua Manoel dos Santos Quialheiro, 1-102, Novo Jardim Pagani, 17024-260, Bauru, SP, Brazil. \\ spereirasoares@yahoo.com.br
}

\begin{abstract}
Homalonotid trilobites (Phacopida) from the Ponta Grossa Formation (Lower Devonian), Paraná State are revised. A total of 156 specimens recovered from rocks that belong to the Jaguariaíva Member (or Sequence B), of the Ponta Grossa Formation cropping out at Ponta Grossa, Tibagi and Jaguariaíva counties, were examined. Data gathered indicate that at least two species are present (Burmeisteria noticus and B. herscheli). B. noticus is a conspicuous species of the Devonian rocks of South Africa (Bokkeveld Group), Argentina (Lipéon Formation), Bolivia (Icla and Bélen Formations), and Brazil (Pimenteiras and Ponta Grossa formations). B. herscheli is common in Devonian strata on the Falkland Islands (Fox Bay Formation), South Africa (Bokkeveld Group), and Bolivia (Icla and Tarija formations), and is a newly recognized member of the trilobite fauna of the Ponta Grossa Formation. Hence, the homalonotid fauna of the Ponta Grossa Formation is not monospecific, as previously assumed. Finally, homalonotids are not randomly distributed throughout the succession of the Ponta Grossa Formation. B. herscheli shows a more restricted bathymetric distribution, preferentially occurring in sandstones and siltstones deposited just at the storm wave base. B. noticus lived and/or were preserved in sedimentary deposits varying from sandy facies, generated just in and/or above the fair weather wave base, and in muddy facies deposited below storm wave base. Despite the differences in the distribution of both species, homalonotid remains are rather abundant in the shallow water facies, deposited jus at or above storm wave base, being potentially important paleoenvironmental (neritic facies) indicators.
\end{abstract}

Key words: Homalonotidae, Systematics, Devonian, Ponta Grossa Formation, Paraná Basin.

RESUMO - São revisados os trilobites da família Homalonotidae (Phacopida), Formação Ponta Grossa (Devoniano), do Estado do Paraná. No total, foram examinados 156 espécimes de homalonotídeos provenientes de rochas equivalentes, litoestratigraficamente, ao Membro Jaguariaíva (=Seqüência B), aflorantes nos municípios de Ponta Grossa, Tibagi e Jaguariaíva. Os dados obtidos permitem inferir que pelo menos duas espécies estão presentes (Burmeisteria noticus e B. herscheli). B. noticus é comum no Devoniano da África do Sul (Grupo Bokkeveld), Argentina (Formação Lipéon), Bolívia (formações Icla e Belén) e Brasil (formações Pimenteiras e Ponta Grossa). B. herscheli ocorre comumente em rochas do Devoniano das Ilhas Falkland (Formação Fox Bay), África do Sul (Grupo Bokkeveld) e Bolívia (formações Icla e Tarija), sendo pela primeira vez referida à fauna de trilobites da Formação Ponta Grossa, sub-bacia Apucarana. Esses dados indicam que a fauna de Homalonotidae da Formação Ponta Grossa não é monoespecífica, conforme anteriormente pensado. Finalmente, os homalonotídeos não estão distribuídos aleatoriamente ao longo da Formação Ponta Grossa. B. herscheli apresenta distribuição batimétrica mais restrita, ocorrendo em depósitos gerados, preferencialmente, junto ou acima do nível de base de ondas de tempestades. B. noticus viveu e/ou foi preservada em fácies arenosas, geradas junto ou acima do nível de base de ondas de tempo-bom até fácies argilosas, depositadas abaixo do nível de base de ondas de tempestades. Em todos os casos, porém, trilobites homalonotídeos são mais abundantes nas fácies de águas mais rasas, depositadas acima do nível de base de ondas de tempestade, sendo potencialmente importantes indicadores paleoambientais.

Palavras-chaves: Homalonotidae, Sistemática, Devoniano, Formação Ponta Grossa, bacia do Paraná. 


\section{INTRODUCTION}

The Devonian invertebrate fauna of the Paraná Basin, Ponta Grossa Formation (Pragian-Emsian, Grahn et al., 2000, 2002; Gaugris \& Grahn, 2006) is one of the most diversified among the Brazilian Paleozoic, benthic marine faunas. These include cnidarians (e.g., conulariids), brachiopods (e.g., linguliforms and rhynchonelliforms), mollusks (e.g., bivalves, gastropods, tentaculids, and cephalopods), echinoderms (e.g., crinoids) and arthropods (mainly trilobites).

In the past 20 years, a number of systematic reviews of the invertebrates of Ponta Grossa Formation have dealt with the Linguliformea (Bosetti, 1989a, b; Bosetti \& Moro, 1989; Zabini, 2007) and Rhynchonelliformea brachiopods (Quadros, 1987), the Mollusca, Bivalvia (Kotzian, 1995; Kotzian, 2003;), Gastropoda (Kotzian \& Marchioro, 1997; Marchioro et al., 1998), and Tentaculida (Ciguel, 1989; Azevedo-Soares, 1999), as well as the Cnidaria, Conularida (Leme, 2002; Leme et al., 2003, 2004). The trilobites, however, have received little attention, and were revised by Popp (1985), Carvalho \& Quadros (1987), and Carvalho \& Edgecombe (1991).

Homalonotids from the Devonian Paraná Basin were first described in 1913, by J.M. Clarke and since then, these trilobites have received little detailed attention in the literature. According to the present state of knowledge, the homalonotids of the Ponta Grossa Formation are represented only by Burmeisteria noticus (= Homalonotus noticus Clarke, 1913) (Clarke, 1895; Clarke, 1913; Kozlowski, 1913; Struve, 1958; Copper, 1977; Eldredge \& Ormiston, 1976; Cooper, 1982; Carvalho \& Edgecombe, 1991; Popp et al., 1996; Ghilardi \& Simões, 2007). When compared with other mid Paleozoic occurrences of the South Hemisphere (e.g., Australia and Falkland Islands), the Paraná Basin homalonotids are still inadequately described and documented. Hence, this contribution deals with homalonotid trilobites essentially coming from an area from where scant data have hitherto been available. Hence, the main goals of the present contribution are to (i) review the systematics of the Devonian homalonotid trilobites of the Ponta Grossa Formation of Paraná Basin, Apucarana Sub-basin, (ii) analyse their taphonomy, and (iii) document the vertical and horizontal distributions of these trilobites in the studied stratigraphic successions.

\section{MATERIAL AND METHODS}

\section{Geological Setting}

In the state of Paraná, Apucarana Sub-basin, Devonian trilobite-bearing rocks of the Ponta Grossa Formation crop out in a series of highways and railroad cuts of Ponta Grossa, Tibagi and Jaguariaíva counties. Sedimentary rocks are mainly represented by interbedded mudstones, highly bioturbated siltstones and fine-grained sandstones deposited on a low gradient shelf of a huge siliciclastic epeiric sea of the Malvinokaffric Realm.

Homalonotid trilobite localities in the Apucarana Subbasin are shown in Figure 1. In addition, the vertical

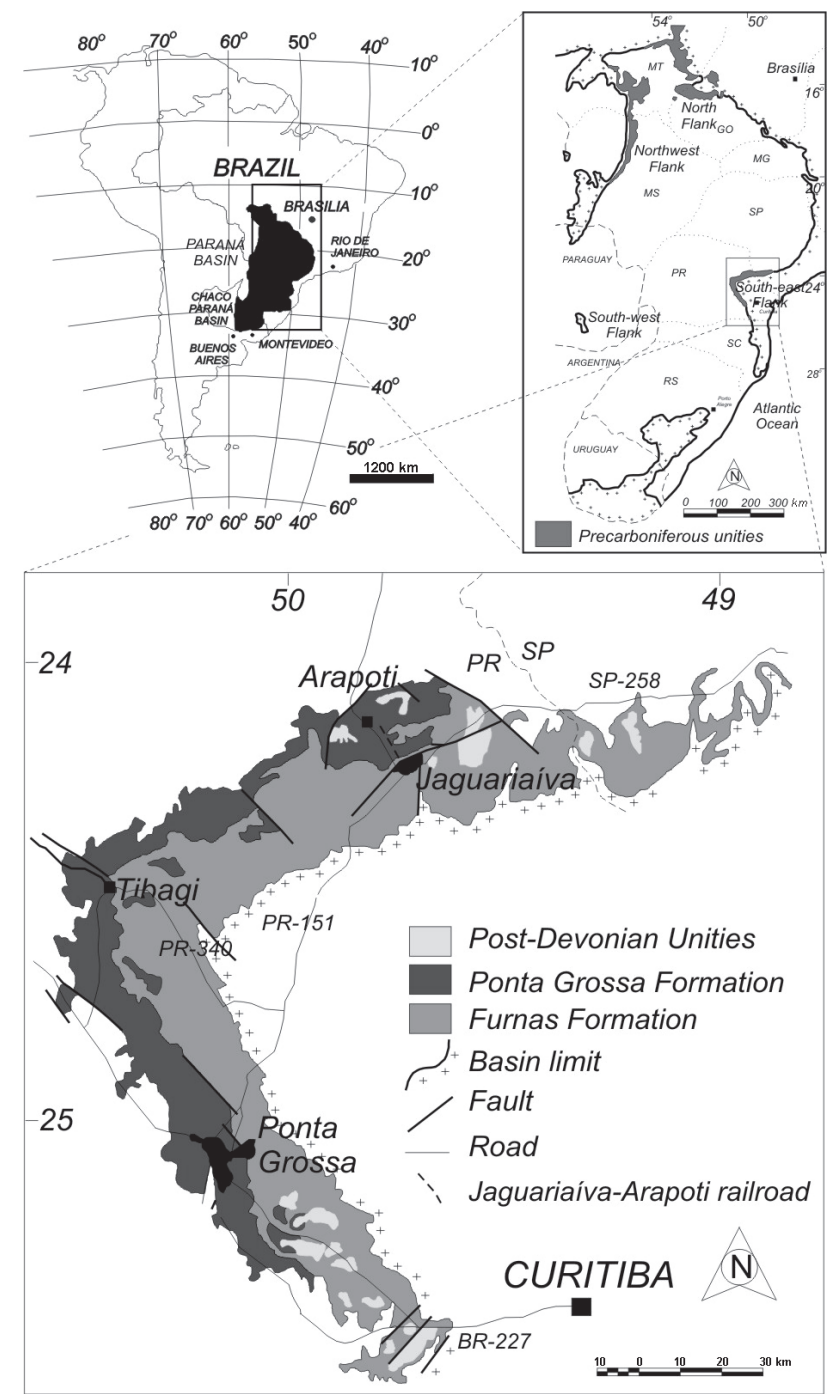

Figure 1. Location map of the studied geological sections, Ponta Grossa Formation, Paraná State, showing the outcrop belt in the eastern margin of Paraná Basin.

distribution of the studied homalonotid trilobites in the sampled stratigraphic sections of the Ponta Grossa Formation is summarised in Figure 2. Homalonotids first appear in Lochkovian rocks (Dino, 1999; Rubinstein et al., 2005; Grahn, 2005; Gaugris \& Grahn, 2006) at the base of the Ponta Grossa Formation.

In Jaguariaíva County (Figure 2A), the Ponta Grossa Formation is up to $80 \mathrm{~m}$ thick and consists predominantly of shales and siltstones (Jaguariaíva Member of Lange \& Petri, 1967 or Sequence B of Bergamaschi, 1999). Shallow marine, fine-grained sandstones bearing wavy structures and hummocky cross-stratification occur at the base of the unit (Petri, 1948; Lange \& Petri, 1967; Melo, 1988). The remainder of the Jaguariaíva stratigraphic section is made up of fairly fossiliferous muddy shelf rocks, mainly light-grayish siltstones, strongly bioturbated, which are intercalated with massive, dark shales. These shales were deposited below storm wave base, and are a record of marine flooding surfaces (Bergamaschi, 1999). Stratigraphic intervals particularly suitable to homalonotid collecting are the railroad cuts at $\mathrm{km}$ 


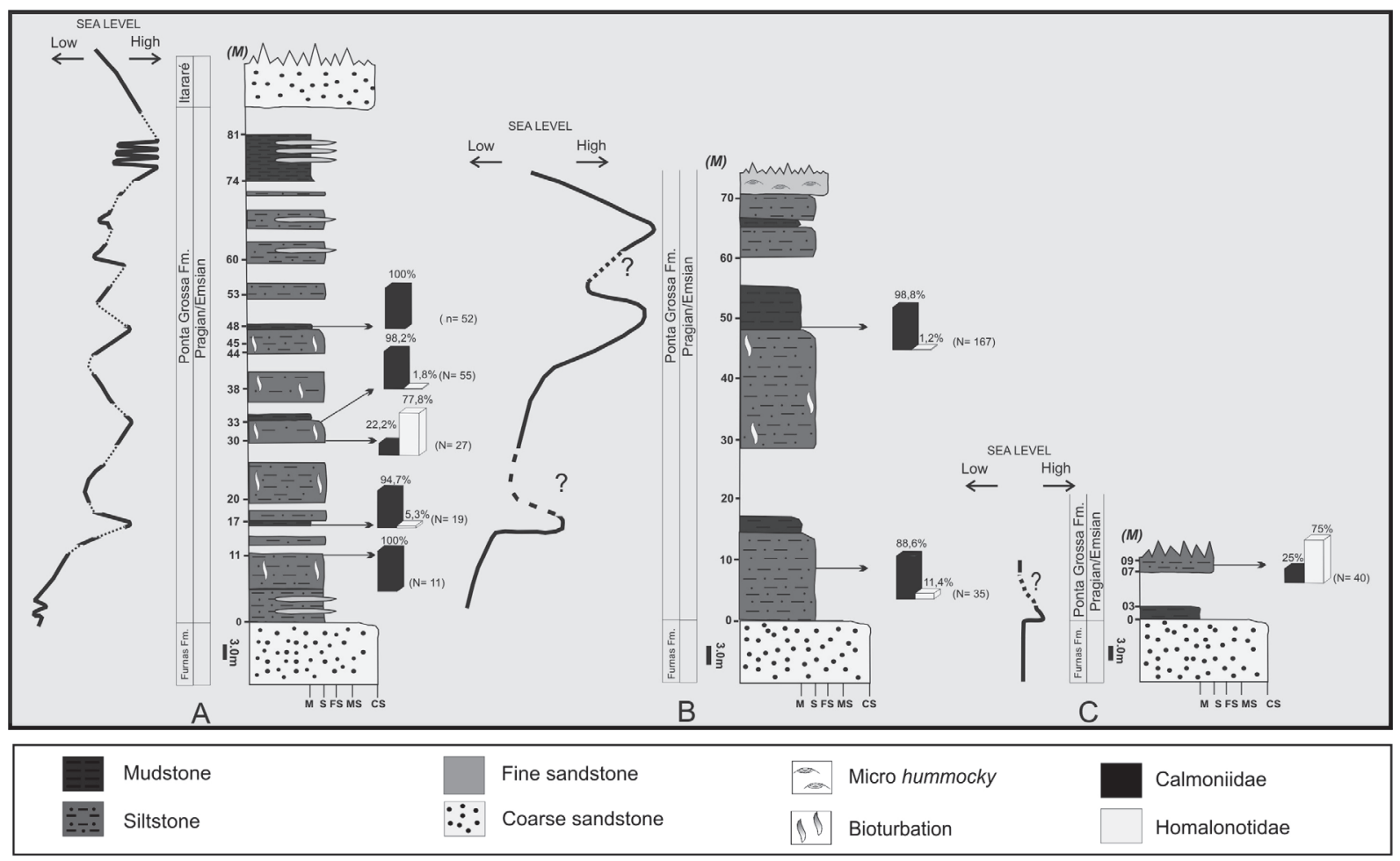

Figure 2. Columnar sections of the Ponta Grossa Formation, Sequence B (=Jaguariaiva Member), showing the vertical and the relative abundance of Calmoniidae and Homalonotidae. M, Mudstone; S, Siltstone; FS, Fine sandstone; MS, Medium sandstone; CS, Coarse sandstone (sections modified from Ghilardi, 2004 and Bosetti, 2004).

2.2, and km 6.0 (Figure 2A). Pyritic, well-laminated, poorly fossiliferous dark shales enclose the Devonian sequence at the top of Jaguariaíva section (Petri, 1948; Lange \& Petri, 1967; Melo, 1988; Bergamaschi, 1999; Bergamaschi \& Pereira, 2001; Figure 2A). According to Bergamaschi (1999), these rocks are recording the transgressive maximum in the area and they were deposited in dysaerobic bottom conditions, as indicated by the scarcity of burrowing fauna.

In the Tibagi region, rocks of the Ponta Grossa Formation were sampled along two main sections. At km 60 of PR-340 road, between the cities of Castro and Tibagi, the first nine meters of rocks of the base of the Ponta Grossa Formation are exposed. These include fairly fossiliferous fine-grained sandstones interbedded with siltstones that were deposited under shallow water conditions (foreshore and shoreface) (Bergamaschi, 1999). Homalonotids were found at the top of the section, nearly $8 \mathrm{~m}$ from the base of the Ponta Grossa Formation (Figure 2B).

A succession of 240 meters of rocks of the Ponta Grossa Formation is cropping out along the first $15 \mathrm{~km}$ of the TibagiTelêmaco Borba highway (Figure 2B). For this study, we sampled the first $70 \mathrm{~m}$ of rocks of Ponta Grossa Formation. Homalonotid trilobites were found in massive mudstones, recording marine flooding conditions (Bergamaschi, 1999; Figure 2B) that are located $48 \mathrm{~m}$ from the base of Ponta Grossa Formation.

In Ponta Grossa County, rocks of the base of the Ponta Grossa Formation are exposed in the so-called "Vila Francelina-outcrop" (Bosetti, 2004) or "Francelina 01- outcrop" (Myszynski \& Bosetti, 2006; Figure 2C). Here, shallow marine, fine-grained sandstones bearing wavy lamination are intercalated in a succession of fossil-rich siltstones (Bosetti, 2004). Homalonotids are particularly abundant in the sandstone layers found $9 \mathrm{~m}$ above the section base.

\section{Data collection}

The revision of the homalonotid trilobites from Apucarana Sub-basin is based on a total of 156 specimens housed in five Brazilian scientific institutions: Universidade Estadual Paulista, Botucatu Campus (UNESP), Universidade Estadual de Ponta Grossa (UEPG), Universidade de Guarulhos (UNG), Universidade de São Paulo (USP), and Universidade Federal do Paraná (UFPR). However, the descriptions that appear in the present contribution are based on 62 specimens (Table 1) deposited in the collection (DZP) of the Departmento de Zoologia, Laboratorio de Paleozoologia Evolutiva, Universidade Estadual Paulista, Botucatu. This is because the stratigraphic position of this material is precisely well-known.

\section{Homalonotid Systematics}

Over the last 60 years, several authors have improved our knowledge about the systematics of the homalonotid trilobites (Gill, 1948; Harrington et al., 1959; Pillet, 1961; Saul, 1965, 1967; Tomczykowa, 1975b; Baldis et al., 1976; Thomas, 1977; Chlupáè, 1981; Henry, 1981; Arbizu, 1982; Cooper, 1982; Busch \& Swartz, 1985; Wenndorf, 1990; Sandford, 2005; Congreve \& Lieberman, 2008). However, despite this considerable body of knowledge, a number of issues mar the study of the 
homalonotids from the Paraná Basin:

(i) Some genera of homalonotids are very variable (e.g., Burmeisteria, see Cooper, 1982; Sandford, 2005) and it may be worth have large collections of it prior the descriptions and taxonomic assignments. Despite of our collecting efforts, only 62 specimens were available to study. They essentially come from the same stratigraphical interval of two main regions (Jaguariaíva, Ponta Grossa). As shown by Carvalho (2006), small collections of homalonotid trilobites may be biased toward an ontogenetic class. Thus, the full range of morphological variation of the studied homalonotids is presently poorly known;

(ii) As properly stated by Carvalho (2005), well-preserved homalonotids are rare in the Devonian of Brazil, and specimens other than those in the available collections are necessary in order to improve systematic comparisons and biogeographic analysis. In fact, homalonotids found in rocks of the Ponta Grossa Formation are generally preserved as molds, showing distinct degrees of anatomical distortion due to compactation (diagenesis) and exfoliation (weathering; see Soares et al., 2008). Weathering is particularly severe in specimens that were exposed or lying close to the outcrop wall. Such specimens show extensive exfoliation and effacement of the glabellar lobation (see Soares et al., 2008). Good examples are the specimens of homalonotids, which were exposed to intense weathering and which are so exfoliated, that the original ornamentation is completely modified or lost. Weathered moults of thoracopygidium of Burmeisteria herscheli (DZP-3390) and B. noticus (DZP-3360) are showed in Figures 3 and 6. Since these processes can modify or efface some morphological features of the homalonotid exoskeleton, we followed the recommendations in Hughes (1995) and Simões et al. (2003) in avoiding the descriptions and diagnoses of species based on morphological characters that originate from, or were modified by taphonomic processes (weathering and diagenesis);

(iii) In addition to the characters above, others seem to be taphonomic in origin as well. For example, "granules" are generally absent on the internal molds of homalonotids, but some of the studied specimens of Burmeisteria herscheli and $B$. noticus have these all over the cephalon and the pygidium. As shown in figure 4, the "granules" are distinct even in poorly preserved areas (notably on the anterior part of the glabella, Figure 4A), which strongly suggests that they are taphonomic in origin. According to Allart van Viersen (personal communication, February 2009), these small "granules" in homalonotids are actually quartz crystals;

(iv) External molds are lacking, which may help us in the identification and description of some characters. Remnants of tubercles, however, can be visible when preservation is favorable, indicating that these may be the base of dorsal spines (see also Carvalho, 2005).

\section{Terminology and Nomenclature}

Despite the studies of Tomczykowa (1975b), Baldis et al. (1976), Chlupáè (1981), and Wenndorf (1990), the terminology used for the descriptions of homalonotid trilobites follow Sandford (2005). This is because Sandford (2005) uses the standard terminology as suggested in Whittington et al. (1997).

As far as the nomenclature, there is some confusion in the literature about the correct spelling of the name herscheli (e.g., Carvalho, 2006) and herschelii (e.g., Sandford, 2005). The former is an invalid emendation because Murchison (1839) actually wrote "Homalonotus Herschelii". Following Cooper (1982) and others (e.g., Carvalho, 2005, 2006) we use Burmeisteria herscheli.

\section{RESULTS \\ Homalonotid trilobites: Stratigraphic Distribution and Taphonomy}

Figure 2 provides an overview of the vertical distribution of homalonotid species along the three studied stratigraphic sections (Ponta Grossa, Tibagi, and Jaguariaíva). In all occurrences homalonotid exoskeletons are preserved as molds, are mainly incomplete (cephala and pygidia) and poorly preserved. Homalonotids are very common in fine-grained sandstones at the base of the Ponta Grossa Formation where shallow water (above fair-weather wave base) conditions prevailed. However, as indicated by their occurrence in massive mudstones and laminated siltstones deposited below storm wave base, homalonotid remains are not confined to these deposits.

In the fine-grained sandstone facies at the base of the Ponta Grossa Formation homalonotid remains can be preserved as articulated (outstretched bodies) and partially articulated remains. In the Ponta Grossa section, Vila Francelina outcrop, basal deposits of the Ponta Grossa Formation contain articulated and partially articulated exoskeletons of Burmeisteria noticus that are associated with disarticulated remains, such as cephala $(\mathrm{n}=4)$, pygidia $(\mathrm{n}=8)$, thorax $(\mathrm{n}=7)$ and isolated sclerites $(\mathrm{n}=8)$. The same condition is also observed in those homalonotid remains found in shallow water deposits (foreshore and shoreface) at the base of the Ponta Grossa Formation by the Castro-Tibagi road (Figure 2), from where the few specimens found all concern isolated and disarticulated remains. These are generally chaotically oriented in the matrix due to the high degree of bioturbation of the host rock. In this way, the original sclerite orientation was modified by deep, intrastratal bioturbation (see Simões et al., 2000; Rodrigues et al., 2003, for a similar example with the co-occuring conularids).

In the Jaguariaíva section, disarticulated homalonotid remains, mainly thorax and thoracic somites of Burmeisteria herscheli and B. noticus, are relatively common in platformal siltstones with fine-grained sandstone layers, bearing hummocky cross-stratification (Figure 2, Table 1). Conversely, in massive mudstones and shales of relatively deep water deposits (below storm wave base) of the same stratigraphic section, homalonotid (B. noticus) exoskeletons (only cephala) are rare.

The relative abundance of the homalonotids throughout the Ponta Grossa Formation is variable. Homalonotiddominated assemblages are present in fine-grained 
Table 1. Vertical distribution of the homalonotid exoskeletal remains and associated trilobite fauna in the Jaguariaíva, Tibagi and Vila Francelina outcrops. Abbreviations: Ceph-thor, cephalon-thorax; Thor-pyg, thorax-pygidium.

\begin{tabular}{|c|c|c|c|c|c|c|}
\hline & \multirow[b]{2}{*}{ Calmoniidae } & \multicolumn{3}{|c|}{ Homalonotidae } \\
\hline & & & & $\begin{array}{c}B . \\
\text { herscheli }\end{array}$ & $\begin{array}{c}B . \\
\text { noticus }\end{array}$ & Indet. \\
\hline \multirow{5}{*}{$\begin{array}{l}\frac{\pi}{\pi} \\
\frac{\pi}{\pi} \\
\frac{\pi}{\pi} \\
\frac{7}{5} \\
\frac{\pi}{7}\end{array}$} & $\begin{array}{l}\boldsymbol{E} \\
\underset{+}{\infty}\end{array}$ & $\begin{array}{l}\text { Cephalon } \\
\text { Ceph-thor } \\
\text { Thorax } \\
\text { Thor-pyg } \\
\text { Pygidium } \\
\text { Somites } \\
\text { Complete }\end{array}$ & $\begin{array}{c}10 \\
5 \\
11 \\
5 \\
13 \\
4 \\
4\end{array}$ & & & \\
\hline & $\underset{\text { ભ }}{E}$ & $\begin{array}{l}\text { Cephalon } \\
\text { Ceph-thor } \\
\text { Thorax } \\
\text { Thor-pyg } \\
\text { Pygidium } \\
\text { Somites } \\
\text { Complete }\end{array}$ & $\begin{array}{c}12 \\
3 \\
13 \\
5 \\
12 \\
7 \\
2\end{array}$ & & 1 & \\
\hline & $\begin{array}{l}\text { E } \\
\text { ○्ల }\end{array}$ & $\begin{array}{l}\text { Cephalon } \\
\text { Ceph-thor } \\
\text { Thorax } \\
\text { Thor-pyg } \\
\text { Pygidium } \\
\text { Somites } \\
\text { Complete }\end{array}$ & $\begin{array}{l}3 \\
1 \\
2\end{array}$ & $\begin{array}{l}1 \\
2\end{array}$ & $\begin{array}{l}2 \\
2\end{array}$ & $\begin{array}{l}7 \\
1 \\
5\end{array}$ \\
\hline & $\begin{array}{l}E \\
\stackrel{E}{\leftarrow}\end{array}$ & $\begin{array}{l}\text { Cephalon } \\
\text { Ceph-thor } \\
\text { Thorax } \\
\text { Thor-pyg } \\
\text { Pygidium } \\
\text { Somites } \\
\text { Complete }\end{array}$ & $\begin{array}{l}1 \\
1 \\
7 \\
3 \\
3 \\
3\end{array}$ & & 1 & \\
\hline & $\underline{\varepsilon}$ & $\begin{array}{l}\text { Cephalon } \\
\text { Ceph-thor } \\
\text { Thorax } \\
\text { Thor-pyg } \\
\text { Pygidium } \\
\text { Somites } \\
\text { Complete }\end{array}$ & $\begin{array}{l}2 \\
2 \\
3 \\
1 \\
3\end{array}$ & & & \\
\hline \multirow{2}{*}{ 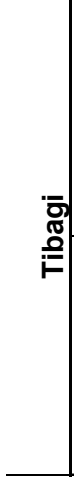 } & $\begin{array}{c}\boldsymbol{E} \\
\underset{+}{\infty}\end{array}$ & $\begin{array}{l}\text { Cephalon } \\
\text { Ceph-thor } \\
\text { Thorax } \\
\text { Thor-pyg } \\
\text { Pygidium } \\
\text { Somites } \\
\text { Complete }\end{array}$ & $\begin{array}{c}22 \\
4 \\
68 \\
18 \\
25 \\
28\end{array}$ & & 1 & 3 \\
\hline & $\begin{array}{l}E \\
\sigma\end{array}$ & $\begin{array}{l}\text { Cephalon } \\
\text { Ceph-thor } \\
\text { Thorax } \\
\text { Thor-pyg } \\
\text { Pygidium } \\
\text { Somites } \\
\text { Complete }\end{array}$ & $\begin{array}{c}2 \\
\\
8 \\
1 \\
9 \\
11\end{array}$ & 1 & & 3 \\
\hline 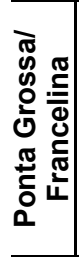 & $\begin{array}{l}\boldsymbol{E} \\
\sigma\end{array}$ & $\begin{array}{l}\text { Cephalon } \\
\text { Ceph-thor } \\
\text { Thorax } \\
\text { Thor-pyg } \\
\text { Pygidium } \\
\text { Somites } \\
\text { Complete }\end{array}$ & $\begin{array}{l}3 \\
2 \\
3\end{array}$ & 2 & $\begin{array}{l}5 \\
1 \\
\end{array}$ & $\begin{array}{l}1 \\
1 \\
7\end{array}$ \\
\hline
\end{tabular}

sandstones in the basal portion of the Ponta Grossa Formation. The most noteworthy example of this type of assemblages is found in the Vila Francelina-outcrop. These assemblages are made up of more than $70 \%(\mathrm{n}=40)$ of homalonotid remains. The remainder is represented by calmoniid trilobites. As indicated by the occurrences in the Jaguariaiva section, a similar condition is also shown by assemblages found in deeply bioturbated siltstones and hummocky cross stratification bearing sandstones of the middle portion of the Ponta Grossa Formation (see Figure 2). However, an opposite pattern is noticed in those assemblages found in mudstones (massive siltstones and shales) where calmoniid remains are more abundant than homalonotid exoskeletons. Good examples are offered by assemblages found in mudstones recording marine flooding surfaces of the middle portion of the Ponta Grossa Formation in the Jaguariaíva and Tibagi sections.

\section{Systematics}

Order PHACOPIDA Salter, 1864

Suborder CALYMENINA Swinnerton, 1915

Superfamily CALYMENOIDEA Burmeister, 1843

Family HOMALONOTIDAE Chapman, 1890

Genus Burmeisteria Salter, 1865

Type species: Homalonotus herscheli Murchison, 1839, p. 652 , by original designation, from the Gydo Formation (Bokkeveld sequence).

\section{Burmeisteria herscheli (Murchison, 1839) \\ (Figures 3A,4A, G, H, 6A)}

Description. Burmeisteria with subtriangular cephalon; length 0.6-0.7 times width, with rounded genal angle. Medially constricted, urceolate glabella; length 0.8-1.2 times width. Tumid triangular genae, convex downward, with small eyes. Deep occipital ring furrow. Long, convex, triangular, sharply pointed pygidium; length 1.0-1.1 times width. Axis is wide, comprising 5 to 12 segments. Large, coarse structures (tubercles) present on the distal extremities of the anterior four pygidial axial rings.

Examined material. DZP-2105; 2108; 2247; 2855; 3367 a,b,c; 3383; 3390; 3391 b,c; 17139 a,b; 17330; 17638 a,b; 17646; 17654 a,b; 17667; UEPG - 1014; 1017 a,b; 1019; 1025; 1033; 1034; 1035 a,b,c; 1042; 1065.

Remarks. The genus Burmeisteria was proposed by Salter (1865), based on South African material, as a subgenus of Homalonotus. Subsequently, Woodward (1903, in Reed, 1918) referred to Burmeisteria as a genus. Clarke (1913) attributed the Devonian Brazilian material to Homalonotus. Notably, in some specimens sketched by Clarke (1913:358, pl.2, figs.2-3) the typical morphological features of Burmeisteria herscheli are present (e.g., triangular, lobated, and medially contracted cephalon). Hence, the specimens cited above and those sketched by Clarke (1913:358) are all referred here as to Burmeisteria herscheli. Additionally, Clarke (1913:96) concluded that homalonotids from South Africa and the 


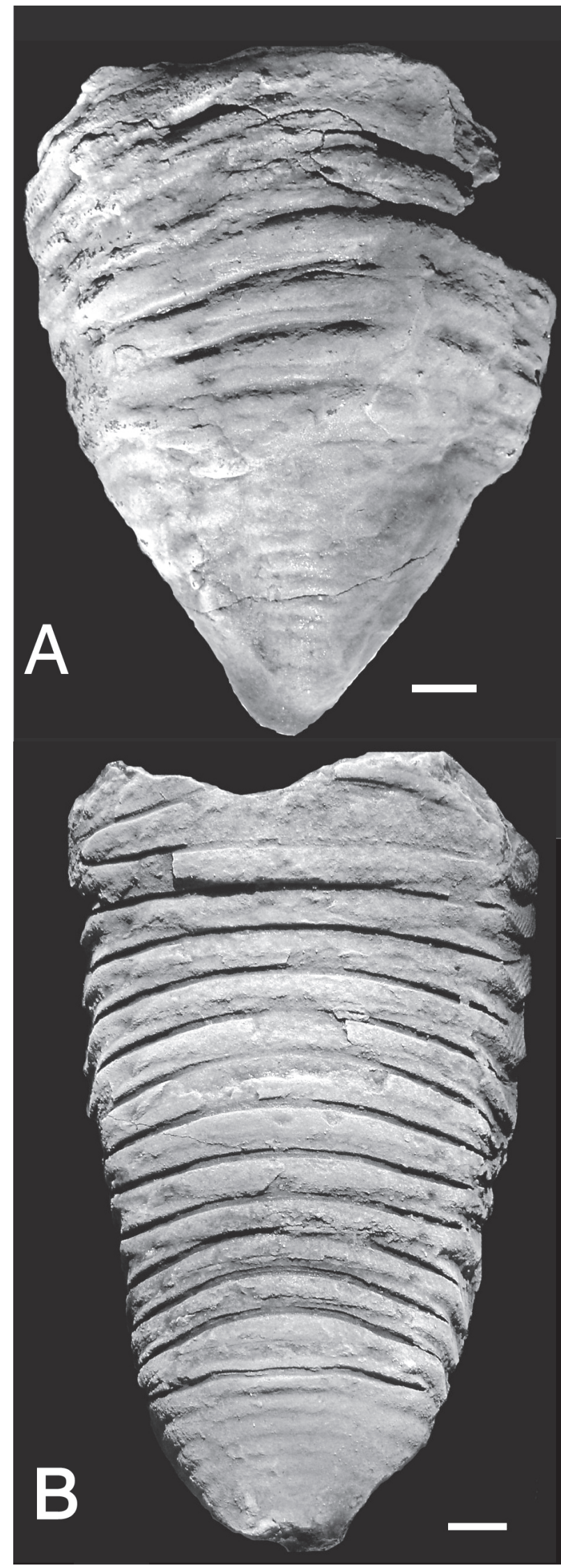

Figure 3. Two moults of Homalonotidae from the Taphofacies T3, Jaguariaíva section. A, DZP-3390, B. herscheli, weathered thoracopygidium; B, DZP-3360a, B. noticus, weathered thoracopygidium. Scale bars $=5 \mathrm{~mm}$.
Falkland Islands are tuberculated (spiny), whereas in the species from North and South America this feature is lacking. Clarke (1913) also noted that in the specimens of Burmeisteria herscheli from the Falkland Islands, the tuberculate condition is variable. The author concluded that the number of tubercles increases with size and age of the homalonotid exoskeletons. In the examined material from the Ponta Grossa Formation, some specimens have tubercles on the pygidia (DZP-2247b, Figure 4G, H). These have the appearance of bases of dorsal spines that are broken off. Both Lake (1904) and Carvalho (2005) have described similar features in other homalonotid species as bases of spines. This is the first occurrence of spiny homalonotids in the Paraná Basin (Figure $4 \mathrm{G}, \mathrm{H})$. The specimen DZP-2855, with $1.34 \mathrm{~cm}$ of width and $1.43 \mathrm{~cm}$ of length, is the smallest studied specimen of Burmeisteria herscheli. In spite of being small, the pygidium of this specimen has the bases of spines preserved. Hence, despite the small number of specimens available in the studied collection, the spines are observed in both large $(2.75 \mathrm{~cm}$ of width and $3.43 \mathrm{~cm}$ length) and small $(1.34 \mathrm{~cm}$ of width and 1.43 cm of length) specimens.

In the examined specimens of Burmeisteria herscheli the number of axial rings in pygidia is variable (5 to 12 ). However, Lake (1904) counted some 13 axial rings in pygidia of South African specimens of $B$. herscheli. In additional pygidia from South Africa that were illustrated by Kennedy (1994) there are more than 13 (14 or 15?). Finally, Sandford (2005) counted 17 pygidial axial rings although he did not mention a source for his observations.

Burmeisteria noticus (Clarke, 1913) (Figures 3B, 4B-F, 6B)

Description. Burmeisteria with subtriangular cephalon, with wide base; rounded genal angles $\left(30^{\circ}-40^{\circ}\right)$; length $0.42-0.45$ times width. Subtrapezoidal glabella, with well-marked shallow axial furrows; lobation absent; length 0.7-1.2 times glabellar width. Mammiform and conspicuous eye lobes, with prominent small eyes. Broad anterior border, terminating in the front part in a transverse margin. Very broad doublure in the front part, making a subtriangular plate, extending within the anterior edge of the glabella, narrowing at the sides, just in front of the eyes, into lateral bands continuous to the occipital ring, forming a shovel-like device. Axial and pleural segmentation distinct; axis with 9 to 13 posterior smooth rings, and 7 to 9 pairs of pleures. Transversally elongated, triangular pygidium; length $0.8-1.0$ times width. Tubercles or the base of spines not observed.

Examined material. DZP-2107 a,b; 2846 a,b; 2848; 3349; 3356 a,b; 3360 a,b,c; 3370 a,b; 3376; 3726; 17301; 17653; 17654 a,b; 17666; 17679; 17680; GSA/IG-USP, GP/1E-5105b, 5113, 5119; UEPG-1018a,b,c; $1022 \mathrm{a}, \mathrm{b} ; 1037 ; 1071$.

Remarks. Based on Sandford's (2005) diagnosis of Digonus, Soares (2007) assigned the specimens of Burmeisteria noticus to Digonus noticus (see also Soares et al., 2008). Indeed, B. noticus bear a trapezoidal glabella with no or weak glabellar lobation, and distinct paraglabellar area, characters 


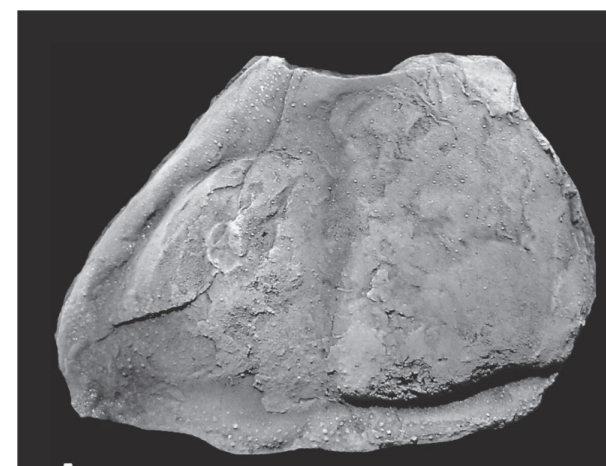

A

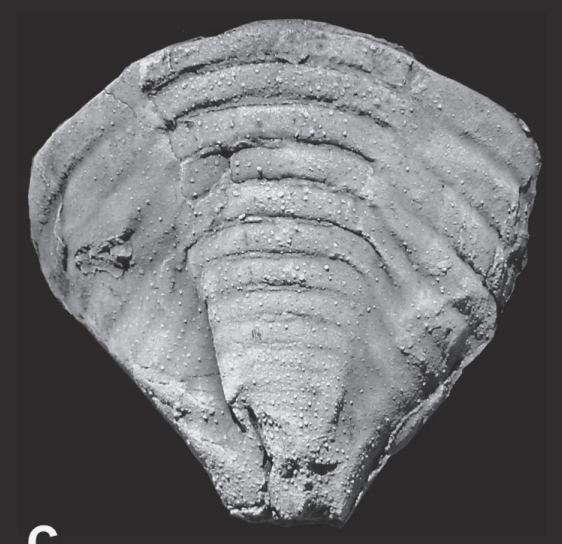

C

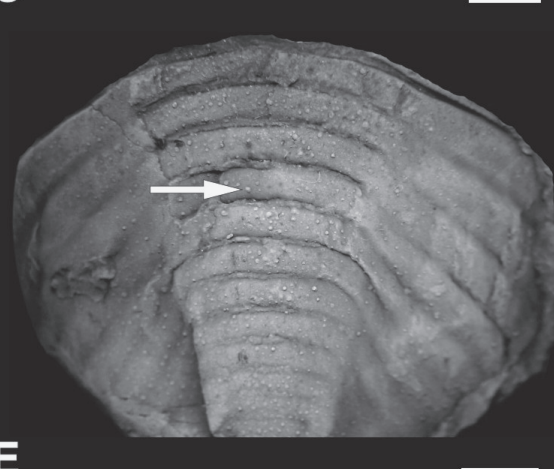

E

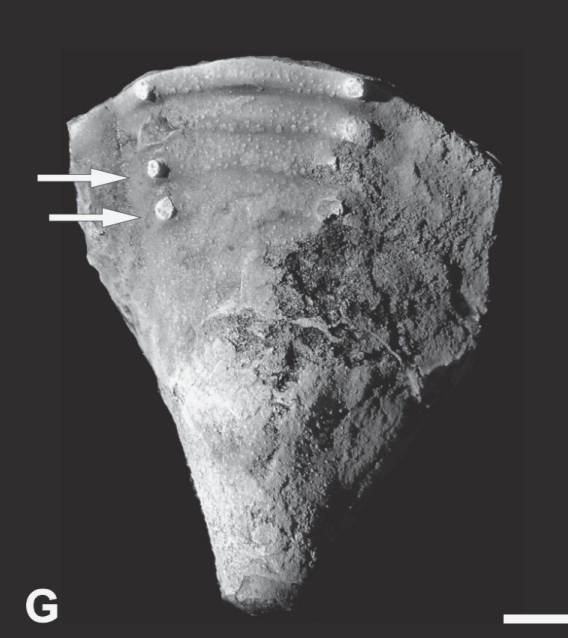

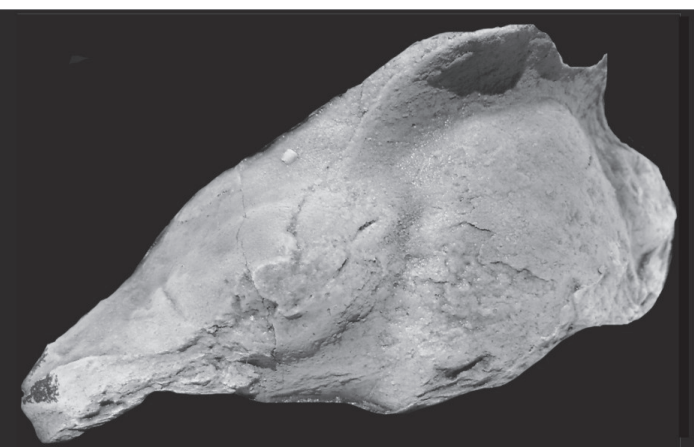

B

D
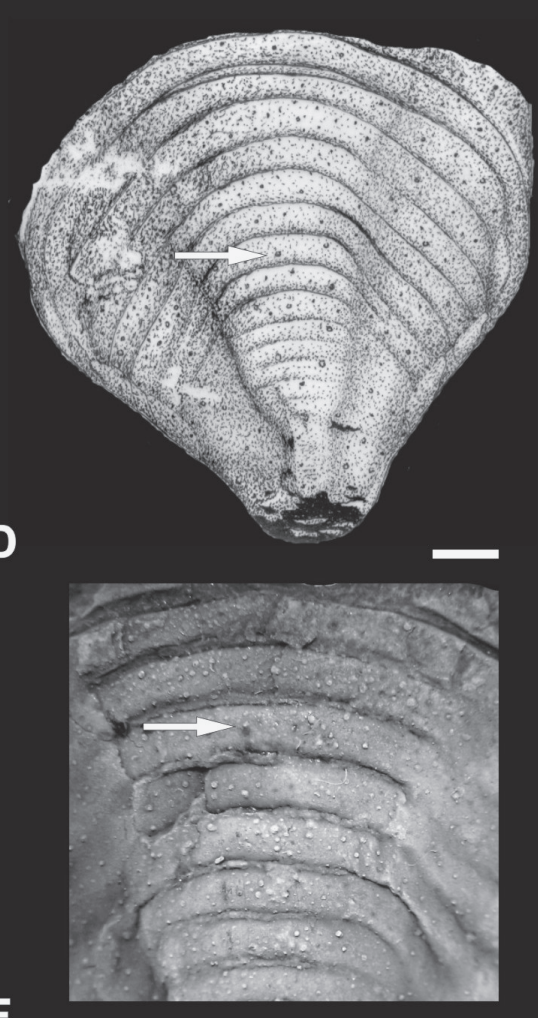

F

H

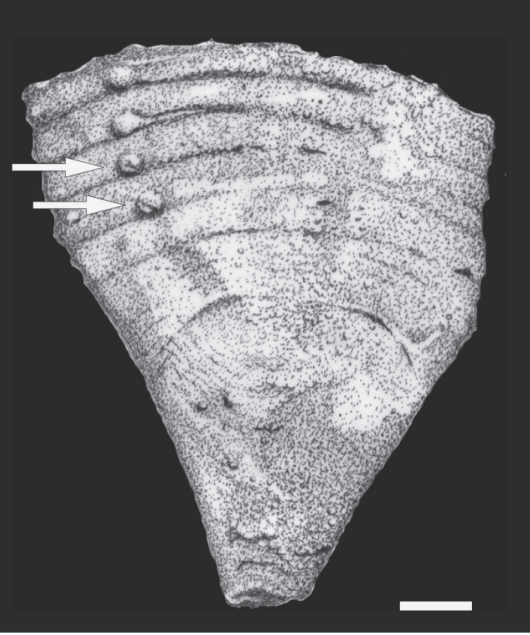

Figure 4. Burmeisteria herscheli and B. noticus. A, DZP-17330, cephalon of $B$. herscheli; B, DZP-2107a, cephalon of B. noticus; C, DZP$3376 a$, subtriangular pygidium of $B$. noticus, with well marked axial furrow; D, DZP-3376a, sketch of the pygidium of $B$. noticus, with scattered granules (arrow); E, DZP-3376a, detail of the pygidium of $B$. noticus, with granules throughout the pygidium (arrow); $\mathbf{F}$, DZP$3376 \mathrm{a}$, granules (arrow) in the pygidium of $B$. noticus; G, DZP-2247b, triangular pygidium of $B$. herscheli, tapering posteriorly, with well marked axial furrow and tubercles distally on axial rings (arrows); H, DZP-2247b, sketch of the pygidium of $B$. herscheli, with tubercles (arrows) distally on the axial rings. Scale bars $=5 \mathrm{~mm}$. 


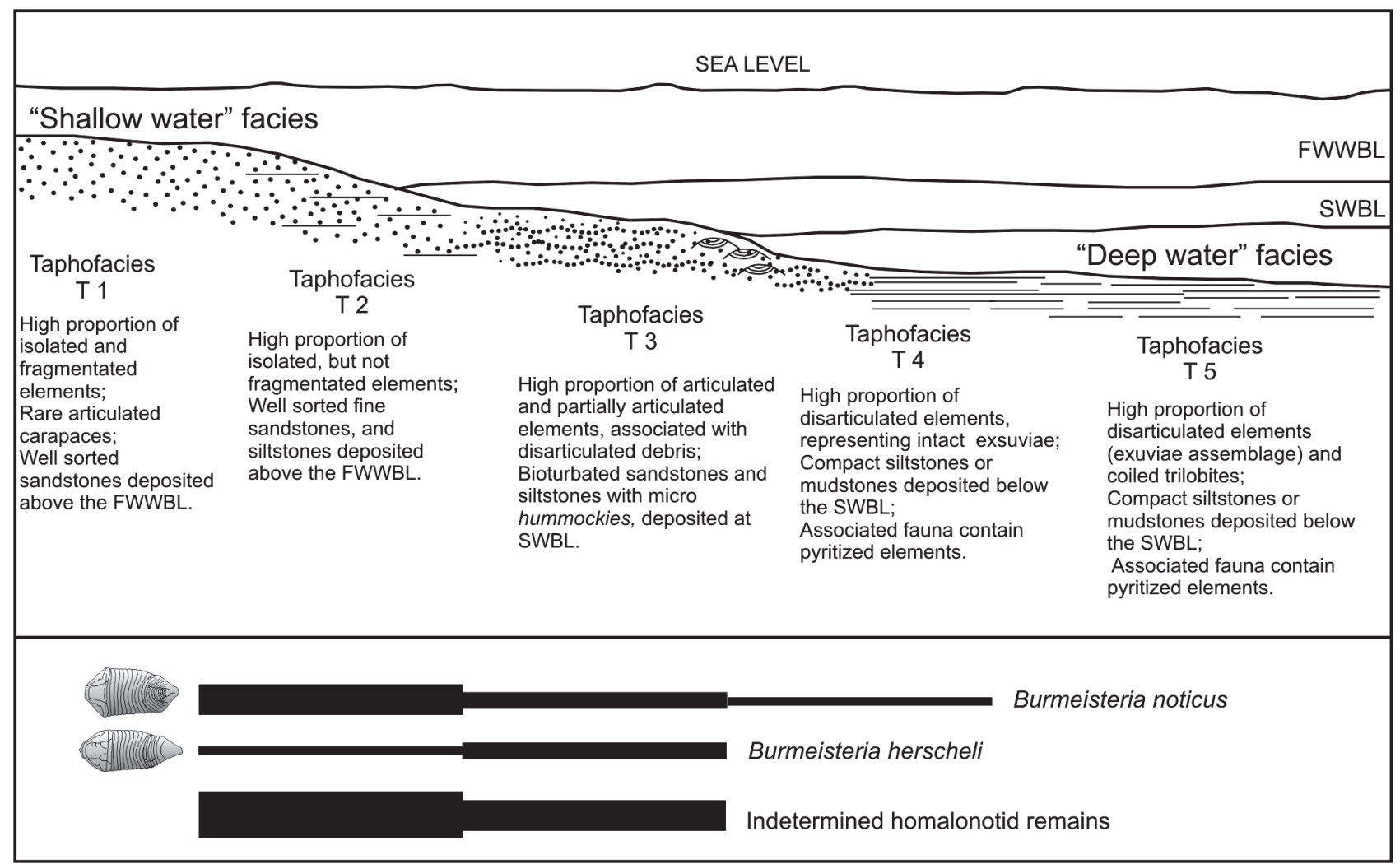

Figure 5. Bathymetric distribution of the homalonotid trilobites throughout the recognized taphofacies, Ponta Grossa Formation, Apucarana Sub-basin (mod. from Sandford, 2005). Abbreviations: FWWBL, fair-weather wave base level; SWBL, storm wave base level.

that are known from Digonus. However, it also exhibits an anteriorly impressed pygidial axial furrow, and shallow ring and pleural furrows, which suggests assignment to Burmeisteria. As commented by A. van Viersen (personal information, 2009) an uninterrupted connection of the anterior pygidial axial ring and associated pleurae (=absence of the axial furrows anterior to the second pygidial axial ring) seems to be a robust apomorphy of Digonus. However, this character is not displayed by B. noticus. In addition, Sandford (2005) stresses that remarkable variability is typical for Burmeisteria, but has never been recorded in Digonus. Unfortunately, our collection is not large enough to test this.

\section{DISCUSSION}

\section{Stratigraphical Distribution, Taphonomy and Paleoecology}

The paleoecology (e.g., Gill, 1948; Chlupáè, 1981; Busch \& Swartz, 1985; Wenndorf, 1990; Whittington, 1993; Sandford, 2005), and stratigraphy/paleobiogeography (Tomczykowa, 1975a, 1975b; Alberti, 1979; Henry, 1981; Cooper, 1982; Wenndorf, 1990; Sandford, 2005; Carvalho, 2006; Congreve \& Lieberman, 2008) of homalonotids is reasonable well known. The vertical distribution and the abundance of the studied homalonotids (Burmeisteria herscheli and B. noticus) is shown in the figure 2 . As mentioned above, fossils of both species occur in rocks of the Ponta Grossa Formation cropping out at the Ponta Grossa, Tibagi and Jaguariaíva sections. These rocks are, locally, representative of deposits of the basal and middle portions of the Ponta Grossa
Formation. Yet, the paleoenvironmental distribution of the studied homalonotid trilobites throughout the Ponta Grossa Formation is shown in Figure 5.

By considering a storm-dominated, shallow to relatively deep water (below storm wave base) bathymetric gradient, as indicated by the rocks in the examined geological sections, homalonotids distribution can be modeled according to three taphofacies (informally referred to as Taphofacies T2 to T4, see Figure 5). Homalonotid species (Burmeisteria herscheli and $B$. noticus) are rather abundant in the shallowest facies (Taphofacies T2, Figure 5) of the studied sedimentary sequence. In those fine-grained sandstone facies homalonotids are predominantly preserved as partly articulated and frequently incomplete exoskeletons or otherwise as isolated cephala and pygidia. Despite the presence of partly articulated exoskeletons, complete fully articulated specimens (outstretched bodies) are rare. Taphofacies T2 comprises autochthonous to parautochthonous (sense Kidwell et al., 1986) occurrences of homalonotids. The associated sedimentary structures (e.g., wavy lamination) indicate that homalonotid remains in this taphofacies represent a near-shore, shallow-water accumulation that was influenced either by water agitation (at normal wave base) or deep intrastratal bioturbation in aerobic bottoms. The accumulations in Taphofacies T2 of our model are equivalent to Taphofacies $1 \mathrm{~b}$ or Taphofacies TII of the Speyer \& Brett (1986) and Sandford $(2002,2005)$ trilobite taphofacies models, respectively. In all these cases 


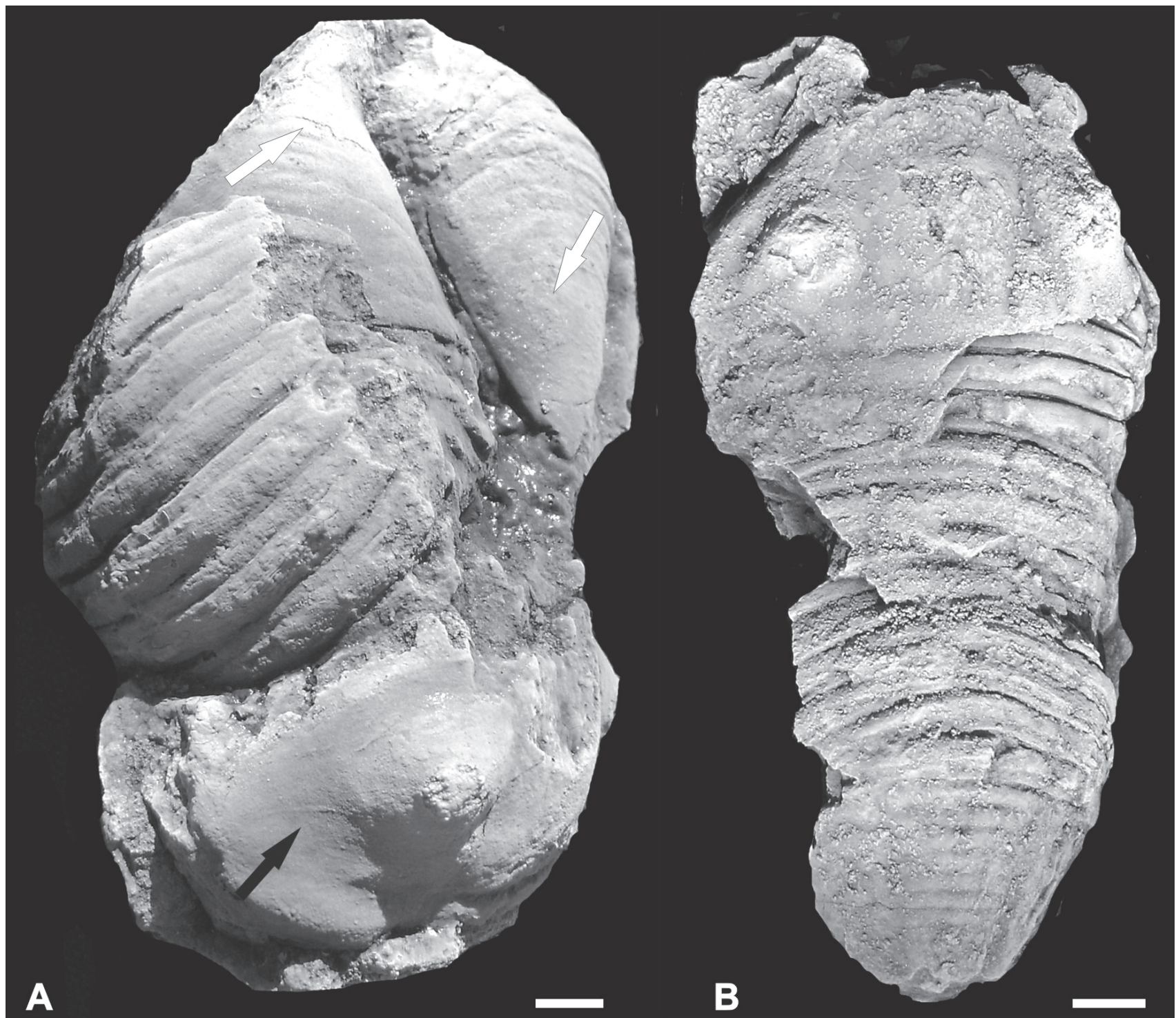

Figure 6. Exoskeletal remains of the Taphofacies T2, Vila Francelina outcrop. A, DZP-17654a, B. herscheli, cephalon (black arrow), pygidia (white arrows); B, DZP-17680a, complete specimen of $B$. noticus. Scale bars $=5 \mathrm{~mm}$.

there is a mixture of partly articulated exoskeletons and isolated sclerites and their association with fine-grained sandstones, deposited in shallow water conditions (above or at fairweather wave base).

The observations above are in accordance with the data of Gill (1948) and Chlupáè (1981). Both authors noticed that during the Devonian, homalonotid trilobites were very abundant in shallow marine, siliciclastic (sand-dominated) inner shelf deposits, than in offshore, muddy bottoms (see also recent data in Crônier \& van Viersen, 2007). In fact, the most spectacular occurrences of homalonotid trilobites, such as those described by Thomas (1979, "Acaste-Trimerus Association”), Fortey \& Owens (1997, “Digonus Biofacies”), Mikulic (1999, "Homalonotid Association") and Sandford (2005, Trimerus moult assemblage) are associated with bioclastic concentrations that were generated in shallow water conditions (between the normal and the storm wave base).

It is noteworthy, however, that both taphonomic and stratigraphic evidences are absent in the proposed taphofacies model, regarding mass accumulations of homalonotid remains in well-sorted sandstones of foreshore (beach face) deposits. Such high energy deposits generally yield dense concentrations of disarticulated and fragmented homalonotid exoskeletons (Taphofacies 1b, Speyer \& Brett, 1986 or Taphofacies TI, Sandford, 2005). The absence of mass accumulations can be explained by the abrupt deepening events recorded in the basal deposits of the Ponta Grossa Formation, associated with the transgressions and floods of coastal and lowland areas of the Devonian Paraná Basin (Melo, 1988; Petri, 2006).

Another condition observed is the preservation of isolated remains such as cephala and pygidia besides thoracopygidia of Burmeisteria noticus and B. herscheli, in bioturbated siltstones to fine-grained sandstones, sometimes showing sedimentary structures, including micro- hummocky cross-stratifications. These occurrences show a mixture of 
already disarticulated remains and relatively intact exuviae, whose preservation depends on calm water and abrupt or at least rapid burial, before the attacks by necrophagous organisms (Speyer \& Brett, 1986). Those fossils were probably deposited in layers generated just in and/ or below storm wave base. This would be a transitional condition between Taphofacies T3 being well-documented in the rock succession of the median portion of the Ponta Grossa Formation, in Jaguariaíva, especially in the interval placed 30 $\mathrm{m}$ from the base of this unit (Figures 2, 5).

Homalonotid occurrences of Taphofacies T4 are associated with muddy rocks, mainly massive siltstones and shales deposited below storm wave base in offshore settings. These deposits are a record of marine flooding events and are well preserved in the middle to upper portion of the Ponta Grossa Formation in the Jaguariíva section (Figure 2). Here, partially articulated, outstretched moult remains (cephalonthorax) and isolated cephala of B. noticus are associated with calmoniid remains, some represented by fully articulated and inflated, outstretched bodies, and pyritized brachiopod shells (e.g., Australocoelia). These deposits represent transgressive events in which organic rich, dysaerobic-anaerobic bottom conditions prevailed. In the Jaguariaiva section, the best examples of Taphofacies T4 are offered by the trilobite occurrences found 33 meters from the base of the Ponta Grossa Formation (Figures 2, 5). The homalonotid remains in these deposits are mixed with autochthonous (e.g., calmnoiids, bivalve shells in life position) and allochthonous (minute fragments of conulariid tests, see Rodrigues et. al, 2003) fossils. Those remains may represent parautochthonous occurrences of the moults that were quickly buried without significant pre- or post-burial disturbance (see also Speyer $\&$ Brett, 1986). Such deposits are equivalent to those of the 4C and TIV/TV taphofacies deposits of the Speyer \& Brett (1986) and Sandford (2005) models, respectively. The data above show that homalonotid remains can occur in several distinct facies across the studied sections.

The data presented here as well as the data recently published by Sandford (2005) are in accordance with the fact that trilobites homalonotid are abundant in shallow-marine siliciclastic, inner shelf facies generated just in or above the fair weather wave base (Chlupáè, 1981; Fortey \& Owens, 1997; Crônier \& van Viersen, 2007). However, some species seem to have had wide bathymetric distribution while others may have been restricted to sandy facies of shallow water or pelitic facies of deeper water bottoms. In fact, some Australian species, such as Wenndorfia lilydalensis, for example, occur in siliciclastic deposits, generated at the storm wave base, in anoxic conditions. Others such as Trimerus jelli are exclusively found in shallow water, sandy bottoms (above the fair-weather wave base, Sandford, 2005). A similar condition is shown by the homalonotids of the Ponta Grossa Formation. In the Jaguariaíva section, for example, the presence of moults of $B$. noticus suggests that these trilobites could live in pelitic bottoms as well (Figure 5). These moults are represented by thoracopygidia that are still articulated, and outstretched (see Speyer, 1987, 1991, for this preservation condition). The transportation of these exoskeletal remains without causing folding, twist or partial rolling is difficult to conceive, once they occur in obrution deposits (see Simões et al., 2000; Rodrigues et al., 2003). Undoubtedly, these moults were quickly buried, without previous disturbance by other organisms, during the rapid settling of mud blankets associated with high energy events (storms). It is curious to notice that complete, articulated and outstretched B. noticus fossils are also found in shallow water deposits, such as in the Taphofacies T2, Vila Francelina outcrop, Ponta Grossa County (Figures 5, 6; Table 1). It is suggestive, though, that B. noticus lived in siliciclastic bottoms, in different bathymetric and granulometric conditions (Figure 5, Table 1).

In the figure 2, the relative abundance between the remains of homalonotids and calmoniids, is shown by stratigraphic intervals. It is noteworthy that an opposite relation exists between these phacopid groups. Homalonotids outnumber calmoniids by far in shallow water, sandy facies, while calmoniids dominate the muddy facies (flooding surfaces) generated below the storm wave base (Figure 2, Table1).

\section{Diversity of the Homalonotid Fauna, Ponta Grossa Formation, Apucarana Sub-basin}

The diversity of the Devonian homalonotid trilobite fauna of the Apucarana Sub-basin is low, especially when compared to other faunas of Silurian and Devonian age. For example, the homalonotid faunas of the Old World Province (sense Eldredge \& Ormiston, 1976), including Australia, New Zealand and north of Africa, are more diversified. These faunas include species of Burmeisteria, Digonus, Dipleura, Homalonotus, Trimerus, and Wenndorfia (Tables 2 and 3). Digonus is the most diversified genus while Burmeisteria occurrences are rare.

The homalonotid faunas of the Malvinokaffric Realm, Andean, Brazilian and South African Provinces (sense Eldredge \& Ormiston, 1976) are less diversified and are dominated by species of Burmeisteria. Comparing the three provinces, the Andean is the one that presents the greatest diversity of homalonotid trilobites, with the occurrences of species of Burmeisteria, Digonus, Dipleura and Homalonotus (see Table 2). On the other hand, the homalonotids of the Brazilian and South African provinces are dominated by species of Burmeisteria (B. herscheli and B. noticus). The rare occurrence of Burmeisterella in the Brazilian Province was recentely documented by Carvalho (2005), based on specimens from the Ponta Grossa Formation (Parecis Basin).

The wide occurrence of species of Burmeisteria in the Malvinokaffric Realm shows that during part of the Devonian age, particularly during the Emsian, there were faunistic communications between the Andean, Brazilian and South African Provinces. Hence, the low diversity of the homalonotid fauna in the Brazilian and South African Provinces seems to be linked to the climatic conditions of this time interval rather than the presence of effective 
Table 2. Devonian Homalonotidae in the Malvinokaffric Realm, according to literature: Clarke (1895); Thomas (1905); Reed (1925); Saul et al. (1963); Castro (1968); Wolfart (1968); Berry \& Boucot (1973); Isaacson (1977); Eldredge \& Branisa (1980); Sanchez \& Benedetto (1983); Oosthuizen (1984); Boucot et al. (1986); Hiller \& Theron (1988); Isaacson \& Sablock (1988); Melo (1988); Rehfeld \& Mehl (1989); Bradshaw \& McCartan (1991); Jell \& Theron (1999); Carvalho (2005); Sandford (2005).

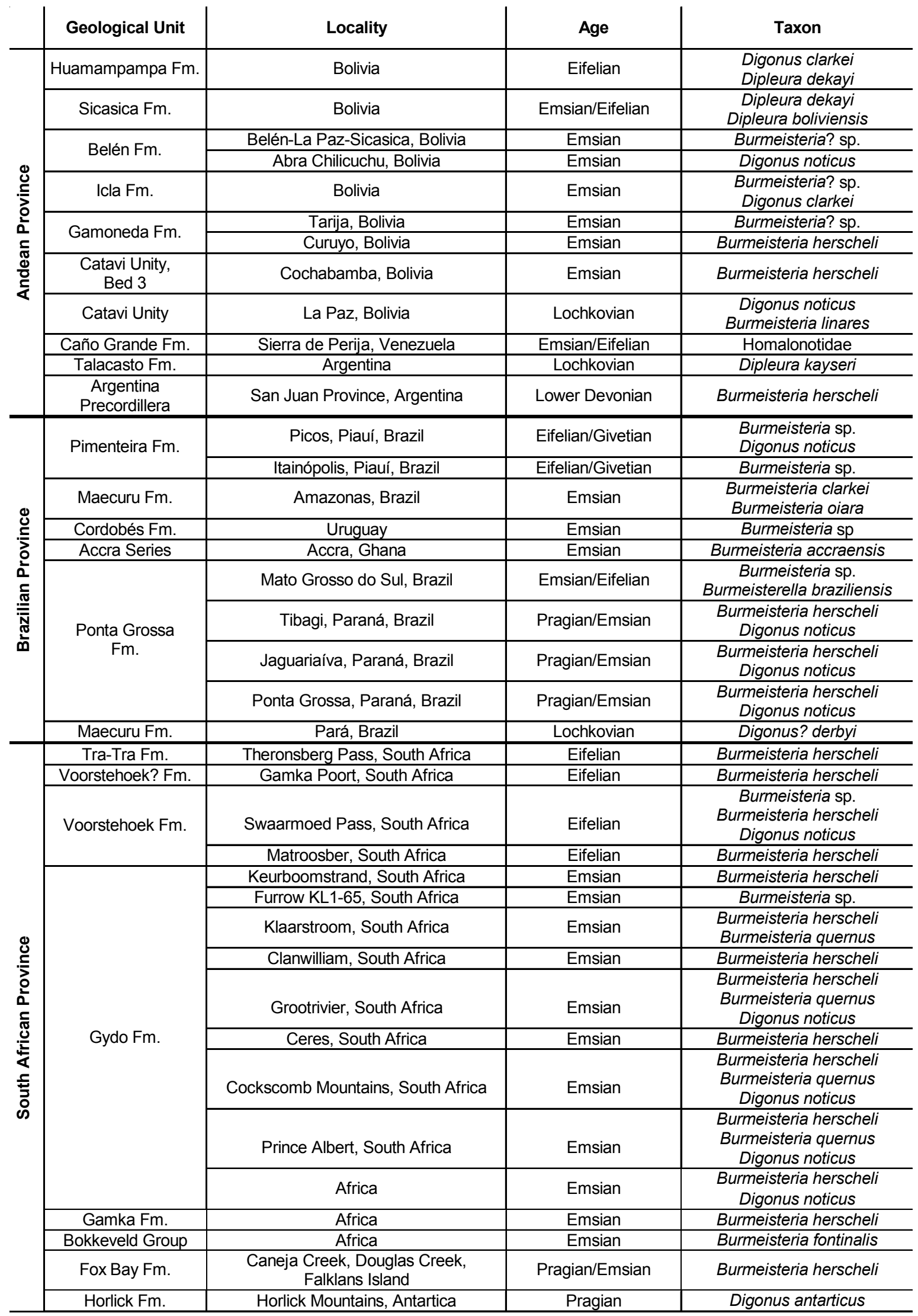


Table 3. Devonian Homalonotidae in the Old World Realm, according to literature: Kegel (1927); Richter \& Richter (1932); Renaud (1942); Pillet (1961); Dubois \& Mazelet (1964); Berry \& Boucot (1973); Hollard (1977); Bradshaw \& Hegan (1983); Wenndorf (1990); Sandford (2005).

\begin{tabular}{|c|c|c|c|}
\hline Geological Unity & Locality & Age & Taxon \\
\hline Atafaitafa Formation & Oued Timesnaguene, Algeria & Lochkovian/Pragian & $\begin{array}{l}\text { Burmeisteria aff. } \\
\text { accuminata }\end{array}$ \\
\hline \multirow{5}{*}{$\begin{array}{l}\text { Zeimlet Formation, El Kseib-Erg } \\
\text { Djemel Section }\end{array}$} & \multirow{5}{*}{ Algeria } & Pragian/Emsian & $\begin{array}{l}\text { Digonus ornatus } \\
\text { disornatus }\end{array}$ \\
\hline & & \multirow{4}{*}{ Lochkovian } & Burmeisteria sp. \\
\hline & & & Burmeisterella cf. armata \\
\hline & & & Digonus roemeri \\
\hline & & & Parahomalonotus sp. \\
\hline \multirow{3}{*}{ Hamar Laghdad Formation } & \multirow{3}{*}{ Anti-Atlas Mountains, Marocco } & \multirow{3}{*}{ Lochkovian/Pragian } & $\begin{array}{c}\text { Digonus cf. } \\
\text { zemmourensis }\end{array}$ \\
\hline & & & Digonus sp. \\
\hline & & & $\begin{array}{c}\text { Parahomalonotus aff. } \\
\text { vialai }\end{array}$ \\
\hline \multirow[t]{5}{*}{ Hamar Laghdad Formation } & Marocco & Pragian & Dipleura sp. \\
\hline & Mauretania, northeastern Africa & Pragian & Digonus armoricanus \\
\hline & \multirow{2}{*}{ Thorigné-en-Charnie, France } & Lochkovian & Digonus zemmourensis \\
\hline & & Lochkovian & Digonus collini \\
\hline & Spain, Asturias & Lochkovian & Digonus asturco \\
\hline Murray Creek Formation & \multirow{2}{*}{ Reefton Region, New Zealand } & \multirow{2}{*}{ Emsian } & \multirow{2}{*}{ Wenndorfia expansa } \\
\hline Bolitho Mudstone & & & \\
\hline $\begin{array}{l}\text { Bell Beds, Boucotia australis } \\
\text { Zone }\end{array}$ & Zeehan, Tasmania, Australia & Lochkovian & Digonus zeehanensis \\
\hline \multirow{2}{*}{$\begin{array}{l}\text { Mt. Ida Formation, Dealba } \\
\text { Member, Stoddart Member }\end{array}$} & \multirow{2}{*}{$\begin{array}{c}\text { Parish of Redcastle, Heathcote, } \\
\text { Victoria, Australia }\end{array}$} & \multirow{2}{*}{ Lochkovian } & Digonus wenndorfi \\
\hline & & & Trimerus jelli \\
\hline $\begin{array}{c}\text { Humevale Siltstone, Boucotia } \\
\text { australis Zone }\end{array}$ & Mooroolbark, Victoria, Australia & Lochkovian & Wenndorfia lilydalensis \\
\hline
\end{tabular}

geographic barriers (see also Melo, 1988, p. 678). During the Devonian, large portions of the Brazilian and South African Provinces were in high latitude (above $60^{\circ} \mathrm{S}$ ) and under temperate-cold weather conditions. Conversely, coeval terrains from Australia and New Zealand were located above $20^{\circ} \mathrm{S}$ and thus in warm weather conditions.

\section{Correlation and Age}

Based on the presence of the chitinozoan Ancyrochitina pachycerata, it is tentatively suggested that the rocks of the Ponta Grossa Formation were deposited in the latest Pragian to late Emsian interval (Gaugris \& Grahn, 2006). The presence of Burmeisteria herscheli and B. noticus in these rocks suggests a Lower to Middle Devonian age for these deposits. The vertical distribution of Burmeisteria herscheli and B. noticus in the Bokkeveld Group, South Africa is well-known by the studies of Oosthuizen (1984) and Hiller \& Theron (1988). In South Africa the argilites of the Gydo Formation (Bokkeveld Group), were deposited in a marine, platformal environment dominated by storms, during the Emsian period (Oosthuizen, 1984). Remains of Burmeisteria herscheli and B. noticus are widely distributed in these argilites. Moreover, in the Karroo Basin massive, black mudstone, equivalent to Gydo Formation, which were pierced through by KL1/65 drilling (see Boucot et al., 1986), contain numerous marine fossils, among which are representatives of Burmeisteria. According to Boucot et al. (1986), these argilites are of Emsian age.

In the Bokkeveld Group, occurrences of Burmeisteria herscheli and B. noticus in post-Emsian rocks are also known, especially in the Voorstehoek and Tra-tra formations, both deposited in the Eifelian. However, as noted by Carvalho (2006), there is a noticible lithostratigraphic similarity between the rock succession of the Gydo (South Africa), Fox Bay (Falkland Islands) and Ponta Grossa formations. Trilobites and brachiopods of the Fox Bay Formation are indicative of an Emsian age, whereas the presence of miospores (Emphanisporites annulus) would indicate a Lower Emsian age (see discussion in Carvalho, 2006). In Bolivia, Cochabamba area, Burmeisteria herscheli also occurs in the Emsian Catavi Formation. On the other hand, Lochkovian rocks of this same litostratigraphic unit, cropping out at $\mathrm{La}$ Paz region, contain specimens of B. noticus found in the socalled "Phacopina chojnacotensis Layers".

In summary, both species (Burmeisteria herscheli, $B$. noticus) are widely distributed in the Malvinokaffric Realm (see Table 2). In fact, based on the literature data alone (without reviewing the fossil collections) both taxa occur in strata of Lochkovian to Givetian age. For example, Burmeisteria herscheli is common in the basal deposits of the Ponta Grossa Formation, as well as in the Gydo Formation, Bokkeveld Group, Karroo Basin, South Africa and Fox Bay Formation, Falkland Islands. In all these places Burmeisteria herscheli is common in Lower Devonian rocks (Emsian), but not restricted to them. The same is also true to $B$. noticus that in the Brazilian Province occur in rocks of Pragian to Givetian age (see Table 2). This may point out to the need for a broad review of those specimens, since such a long stratigraphic extent is highly unusual for a trilobite species. 


\section{CONCLUSIONS}

According to this study, the homalonotid fauna of the Apucarana Sub-basin, Devonian, includes at least two species, namely: Burmeisteria noticus and B. herscheli. The latter is very common in the faunas of the Malvinokaffric Realm, especially in the Bokkeveld Group, South Africa and Fox Bay Formation, Falkland Islands (see Carvalho, 2006). The occurrence of this species in deposits of the Ponta Grossa Formation is described for the first time. Hence, contrary to the present view, the homalonotid fauna of the Paraná Basin is not monospecific;

The taphonomic processes, especially weathering and compactation can modify the original morphology of the studied homalonotids (see Soares et al., 2008, for details), leading to inaccurate anatomical descriptions. For example, some characters such as the granules may be taphonomic in origin;

The homalonotids are not randomly distributed throughout the sedimentary succession of the Ponta Grossa Formation. Articulated or partially articulated specimens, especially of Burmeisteria noticus are rather abundant in sandy facies (Taphofacies T2). These were generated in shallow water conditions, above or just in the fair weather wave base. However, the homalonotids are not restricted to this taphofacies. They also occur in massive mudstones of the Taphofacies TIV, generated below storm wave base;

Both homalonotid species (B. noticus, B. herscheli) of the Ponta Grossa Formation are widely distributed in Devonian strata. B. herscheli is common in the Gydo Formation, South Africa, and Fox Bay Formation, Falkland Islands, reinforcing the correlation between these units and part of the Ponta Grossa Formation, as already suggested from other paleontological and stratigraphical data (see references and discussion in Carvalho, 2006).

\section{ACKNOWLEDGMENTS}

The authors are deeply indebted to M.J. Garcia, L.E. Anelli, E. Bosetti, R.T. Bolzon, R.P. Ghilardi, M.G.P. de Carvalho, B.G. Waisfeld, and J.J. Rustán, who helped us in different stages of this study. The final version of this paper was considerable improved by the comments and suggestions of A. van Viersen and M. Basse. Financial support was provided by FAPESP (05/00791-1).

\section{REFERENCES}

Alberti, H. 1979. Devonian Trilobite biostratigraphy. Special Papers in Palaeontology, 23:313-324.

Arbizu, M. 1982. Trilobites Homalonotinae del Devonico de La Cordillera Cantabrica (NO de España). Trabajos de Geología, 12:243-250.

Azevedo-Soares, H.L.C. 1999. Classe Tentaculita na da Formação Ponta Grossa: uma proposta de sistematização. Programa de Pós-graduação em Análise de Bacias e Faixas Móveis, Universidade Estadual do Rio de Janeiro, Dissertação de Mestrado, $132 \mathrm{p}$.
Baldis, B.A.; Benedetto, L.; Blasco, G. \& Martel, M.E. 1976. Trilobites Silurico-Devonicos de la Sierra de Zapla (Nordeste de Argentina). Ameghiniana, 23(3/4):185-203.

Bergamaschi, S. 1999. Análise estratigráfica do Siluro-Devoniano (Formação Furnas e Ponta Grossa) da sub-bacia de Apucarana, Bacia do Paraná, Brasil. Programa de Pós-graduação em Geologia Sedimentar, Universidade de São Paulo, Tese de Doutorado, $167 \mathrm{p}$.

Bergamaschi, S. \& Pereira, E. 2001. Caracterização de Seqüências Deposicionais de 3a ordem para o Siluro-Devoniano da SubBacia Apucarana, Bacia do Paraná, Brasil. Ciência Técnica Petróleo, Seção Exploração de Petróleo, 20:63-72.

Berry, W.B.N. \& Boucot, A.J. 1973. Correlation of the African Silurian rocks. Geological Society of America Special Paper, 147:1-83.

Bosetti, E.P. 1989a. Proposição de uma sistemática artificial para lingulídeos fósseis, baseada no estudo de lingulídeos da Formação Ponta Grossa (Devoniano), Bacia do Paraná, Brasil. In: XI CONGRESSO BRASILEIRO DE PALEONTOLOGIA, 1, 1989. Anais, Curitiba, UFPR, p. 53-71.

Bosetti, E.P. 1989b. Revisão sistemática dos Lingulida (Brachiopoda : Inarticulata) da Formação Ponta Grossa (Devoniano), Bacia do Paraná, Brasil. In: XI CONGRESSO BRASILEIRO DE PALEONTOLOGIA, 1, 1989. Anais, Curitiba, UFPR, p. $72-$ 89.

Bosetti, E.P. 2004. Tafonomia de alta resolução das fácies de offshore da sucessão devoniana na região de Ponta Grossa, Paraná, Brasil. Programa de Pós-graduação em Geociências, Universidade Federal do Rio Grande do Sul, Porto Alegre, Tese de Doutorado, $112 \mathrm{p}$.

Bosetti, E.P. \& Moro, N.S. 1989. Análise da estrutura e diversidade morfotípica de lingulídeos em algumas paleocomunidades fossilizadas in situ na Formação Ponta Grossa (Devoniano), Bacia do Paraná, Brasil In: XI CONGRESSO BRASILEIRO DE PAlEONTOLOGIA, 1, 1989. Anais, Curitiba, UFPR, p. 92-104.

Boucot, A.J.; Eldredge, N.; Gray, J.; Pojeta, J. A. \& Theron, J.N. 1986. Devonian invertebrates from the Bokkeveld Group below the Karoo succession near Sutherland. Annals of the Geological Survey of South Africa, 20:119-128.

Bradshaw, M.A. \& Hegan, B.D. 1983. Stratigraphy and structure of the Devonian rocks of Inangahua Outlier, Reefton, New Zealand. New Zealand Journal of Geology and Geophysics, 26(4):325-344.

Bradshaw, M.A. \& McCartan, L. 1991. Palaeoecology and systematics of Early Devonian bivalves from the Horlick Formation, Ohio Range, Antarctica. Alcheringa, 15(1):1-42.

Burmeister, H. 1843. Die Organisation der Trilobiten aus ihren lebenden Verwandten entwickelt; nebst einer systematischen Übersicht aller seither beschriebenen Arten. Berlin, Reimer, $174 \mathrm{p}$.

Busch, R.M. \& Swartz, F.M. 1985. Molting and description of a new homalonotid trilobite from Pennsylvania. Journal of Paleontology, 59(5):1062-1074.

Carvalho, M.G.P. 2006. First occurrence of Burmeisterella (Trilobita, Homalonotidae) from the Devonian of Brazil (Parecis Basin), with description of a new species. Arquivos do Museu Nacional, Rio de Janeiro, 63(3):451-458.

Carvalho, M.G.P. 2006. Devonian trilobites from the Falkland Islands. Palaeontology, 49(1):21-34.

Carvalho, M.G.P. \& Quadros, L.P. 1987. Trilobitas devonianos do flanco noroeste da Bacia do Paraná. In: X CONGRESSO BRA- 
SILEIRO DE PALEONTOLOGIA, 2, 1987. Anais, Rio de Janeiro, PETROBRAS, p.545-565.

Carvalho, M.G.P. \& Edgecombe, G.D. 1991. Lower-early middle Devonian calmoniid trilobites from Mato Grosso, Brazil, and related species from Paraná. American Museum Novitates, 3022:1-13

Castro, J.S. 1968. Trilobitas da Formação Pimenteiras, Devoniano do estado do Piauí. Annais da Academia Brasileira de Ciências, 40(4):481-489.

Chapman, E. 1890. Some remarks on the classification of the trilobites as influenced by stratigraphical relations: with outline of a new grouping of these forms. Transactions of the Real Society of Canada 7(4):113-120.

Chlupáè, I. 1981. Homalonotid Trilobites from the metamorphic Devonian of the Hrubý Jeseník Mts., Czechoslovakia. Casopis pro Mineralogii a Geologii, 26(4):361-370.

Ciguel, J.H.G. 1989. Bioestratigrafia dos Tentaculoidea no flanco oriental da Bacia do Paraná e sua ocorrência na América do Sul (Ordoviciano-Devoniano). Programa de Pós-graduação em Geologia Sedimentar, Universidade de São Paulo, Dissertação de Mestrado, $237 \mathrm{p}$.

Clarke, J.M. 1895. As trilobitas do grez de Ereré e Maecurú. Archivos do Museu Nacional, 9:1-58.

Clarke, J.M. 1913. Fósseis devonianos do Paraná. Monografia do Serviço Geológico e Mineralógico do Brasil, 1:1-353.

Congreve, C.R. \& Lieberman, B.S. 2008. Phylogenetic and biogeographic analysis of Ordovician Homalonotid trilobites. The Open Paleontology Journal, 1:24-32.

Cooper, M.R. 1982. A revision of the Devonian (Emsian-Eifelian) Trilobita from the Bokkeveld Group of South Africa. Annals of the South African Museum, 89(1):1-174.

Copper, P. 1977. Paleolatitudes in the Devonian of Brazil and the Frasnian-Famennian mass extinction. Palaeogeography, Palaeoclimatology, Palaeoecology, 21:165-207.

Crônier, C. \& van Viersen, A. 2007. Trilobite palaeobiodiversity during the Devonian in the Ardennes Massif. Bulletin de la Société Géologique de France, 178(6):473-483.

Dino, R. 1999. Palynostratigraphy of the Silurian and Devonian Sequence of the Paraná Basin, Brazil. In: Ordovician-Devonian Palynostratigraphy in Western Gondwana: Update, Problems and Perspectives. Rio de Janeiro, UERJ, p. 27-55.

Dubois, P. \& Mazelet, P. 1964. Stratigraphie du Silurien du Tassili N'Ajjer. Bulletin de la Société Géologique de France (Serie 7), 6(4):586-591.

Eldredge, N. \& Ormiston, A.R. 1976. Biogeography of Silurian and Devonian Trilobites of the Malvinokaffric Realm. In: A.J. Boucot \& J. Gray (eds.). Historical Biogeography, Plate Tectonics, and Changing Environment, Oregon State University Press, p. 147-167.

Eldredge, N. \& Branisa, L. 1980. Calmoniid trilobites of the Lower Devonian Scaphiocoelia Zone of Bolivia, with remarks on related species. Bulletin of the American Museum of Natural History, 165(2):181-289

Fortey, R.A. \& Owens, R.M. 1997. Evolutionary history. In: H.B. Whittington et al. (eds.), Treatise on invertebrate Paleontology, Part O. Arthropoda 1. Trilobita (revised). Volume 1: Introduction, Order Agnostida, Order Redlichiida. Geological Society of America and University of Kansas Press, p. 249287.

Gaugris, K.A. \& Grahn, Y. 2006. New chitinozoan species from the Devonian of the Paraná Basin, south Brazil, and their biostratigraphic significance. Ameghiniana, 43(2):293-310.
Ghilardi, R.P. 2004. Tafonomia comparada e Paleoecologia dos Macroinvertebrados (ênfase em Trilobitas), da Formação Ponta Grossa (Devoniano, Sub-bacia Apucarana), Estado do Paraná, Brasil. Programa de Pós-graduação em Geologia Sedimentar, Universidade de São Paulo, Tese de Doutorado, 113 p.

Ghilardi, R.P. \& Simões, M.G. 2007. History and development of trilobite research in Brazil. New York State Museum Bulletin, 507:97-104.

Gill, E.D. 1948. Palaeozoology and taxonomy of some Australian homalonotid trilobites. Proceedings of the Royal Society of Victoria, 61:61-72.

Grahn, Y. 2005. Devonian chitinozoan biozones of Western Gondwana. Acta Geologica Polonica, 55(3):211-227

Grahn, Y.; Pereira, E. \& Bergamaschi, S. 2000. Silurian and Lower Devonian chitinozoan biostratigraphy of the Paraná Basin in Brazil and Paraguay. Palynology, 24:147-176.

Grahn, Y.; Pereira, E. \& Bergamaschi, S. 2002. Middle and Upper Devonian chitinozoan biostratigraphy of the Paraná Basin in Brazil and Paraguay. Palynology, 26:135-165.

Harrington, H.J. et al. 1959. Trilobita. In: R. C. Moore (ed.) Treatise on Invertebrate Paleontology Part $O$. Arthropoda, Geological Society of America and University of Kansas Press, p. 38-526.

Henry, J.L. 1981. Quelques trilobites Homalonotidae et leur distribution dans l'Ordovicien du Massif Armoricain. Bulletin de la Société Géologique de France, 7(4):345-351.

Hiller, N. \& Theron, J. N. 1988. Benthic communities in the South African Devonian. Canadian Society of Petroleum Geologists Memoir, 14:229-242.

Hollard, H. 1977. Le domaine de l'Anti-Atlas au Maroc. In: A. Martinsson (ed.) The Silurian-Devonian boundary (IUGS, Series A, Number 5,. Schweizerbartsche, p. 168-194.

Hughes, N.C. 1995. Trilobite taphonomy and taxonomy: a problem and some implications. Palaios, 10:283-285.

Isaacson, P.E. 1977. Devonian stratigraphy and brachiopod paleontology of Bolivia. part A: Orthida and Strophomenida. Palaeontographica Abteilung A, 155(5/6):133-192.

Isaacson, P.E. \& Sablock, P.E. 1988. Devonian System in Bolivia, Peru, and northern Chile. Canadian Society of Petroleum Geologists Memoir, 14:719-728.

Jell, P.A. \& Theron, J.N. 1999. Early Devonian echinoderms from South Africa. Memoirs of the Queensland Museum, 43(1):115199.

Kegel, W. 1927. Homalonotus asturco n. sp. aus dem Unterdevon Asturiens. Centralblatt für Mineralogie, Geologie und Palaeontologie. Abteilung B, 8:334-340.

Kennedy, R.J. 1994. British Devonian trilobites. Part 1. Monograph of the Palaeontographical Society, 148(595):1-33.

Kidwell, S.M.; Fürsich, F.T. \& Aigner, T. 1986. Conceptual framework for the analysis of fossil concentrations. Palaios, 1:228-238.

Kotzian, C.B. 1995. Estudo sistemático e morfofuncional de bivalves (Mollusca) das Formações Vila Maria (Siluriano) e Ponta Grossa (Devoniano), Bacia do Paraná, Brasil: interpretação do regime hidrodinâmico-sedimentar. Programa de Pós-graduação em Geociências, Universidade Federal do Rio Grande do Sul, Tese de Doutorado, $378 \mathrm{p}$.

Kotzian, C.B. 2003. A new Devonian Modiolopsidae (Mollusca: Bivalvia) from the Ponta Grossa Formation, Paraná Basin, Brazil. Pesquisas em Geociências, 30(2):27-32.

Kotzian, C.B. \& Marchioro, A. 1997. Gastrópodes (Mollusca) devonianos da Formação Ponta Grossa (Bacia do Paraná). Gêneros: Ptomatis Clarke, 1899, Pleurotomaria (?) Defrance, 1826 
e Platyceras Conrad, 1840. Ciência e Natura, 19:143-185.

Kozlowski, R. 1913. Fossiles devoniens de l'État de Paraná (Brésil). Annales de Paleontologie, 8:14-19.

Kozlowski, R. 1923. Faune dévonienne de Bolivie. Annales de Paleontologie, 12(1/2):1-112.

Lake, P. 1904. The trilobites of the Bokkeveld Beds. Annals of the South African Museum, 4:1-4.

Lange, F.W. \& Petri, S.1967. The Devonian of the Paraná Basin. Boletim Paranaense de Geociências, 21/22:5-55.

Leme, J.M. 2002. Revisão Sistemática dos Conulatae Collins et al. 2000, Formação Ponta Grossa, Devoniano (?LochkovianoFrasniano), Bacia do Paraná, Brasil: implicações paleobiogeográficas e comentários sobre as relações filogenéticas entre os Conulatae. Programa de Pós-graduação em Geologia Sedimentar, Universidade de São Paulo, Dissertação de Mestrado, 112 p.

Leme, J.M.; Heredia, S.; Rodrigues, S.; Simões, M.G.; Acenolaza, G.F. \& Milana, J.P. 2003. Teresconularia gen. nov. from the Lower Ordovician of the Cordillera Oriental of Salta (NW Argentina): the oldest conulariid (Cnidaria) from the South America. Revista Española de Micropaleontologia, 3(35):265-273.

Leme, J.M.; Rodrigues, S.C.; Simões, M.G. \& Van-Iten, H. 2004. Sistemática dos conulários (Cnidária) da Formação Ponta Grossa (Devoniano), Estado do Paraná, Bacia do Paraná, Brasil. Revista Brasileira de Paleontologia, 7(2):213-222.

Marchioro, A.; Kotzian, C.B. \& Simões, R.I. 1998. Belerofontinas (Mollusca:Gastropoda?) devonianos do Estado do Paraná (Formação Ponta Grossa, Bacia do Paraná): gênero Bucanella Meek, 1871. Ciência e Natura, 20:143-185.

Melo, J.H.G. 1988. The Malvinokaffric realm in the Devonian of Brazil. Canadian Society of Petroleum Geologists Memoir, 14:669-703.

Mikulic, D.G. 1999. Silurian trilobite associations in North America. In: A.J. Boucot \& J.D. Lawson (eds). Palaeocommunities: a cesa study from the Silurian and Lower Devonian, Cambridge University Press, p. 793-798.

Murchison, R.I. 1839. The Silurian System, founded on geological researches in the counties of Salop, Hereford, Radnor, Montgomery, Caermarthen, Brecon, Pembroke, Monmouth, Worcester, Gloucester and Stafford; with descriptions of the coalfields and overlying formations. London, John Murray, 2:568-768.

Myszynski, L.J. \& Bosetti, E. 2006. Corredor de afloramentos da sucessão devoniana (?Lockoviano-Frasniano) do Bairro de Uvaras, Ponta Grossa, Paraná, Brasil. In: ENCONTRO ANUAL DE INICIAÇÃO CIENTIFICA, 15, 2006. Anais, Ponta Grossa, UEPG, CDROM.

Oosthuizen, R.D.F. 1984. Preliminary catalogue and report on the biostratigraphy and palaeogeographic distribution of the Bokkeveld fauna. Transactions of the Geological Society of South Africa, 87:125-140.

Petri, S. 1948. Contribuição ao estudo do Devoniano paranaense. Boletim do Departamento Nacional de Produção Mineral, 129:1125.

Petri, S. 2006. Problems in the utilization of the Brazilian Code of Stratigraphic Nomenclatures as related to modern researches. Revista Brasileira de Geociências, 36(1):203-208.

Pillet, J. 1961. Contribution à l'étude des Homalonotidae (Trilobita) des Grès à Dalmanella monnieri (Siegenian inférieur) du Massif armoricain. Bulletin de la Société Géologique de France, 7: 457462

Popp, M.T.B. 1985. Revisão dos trilobitas calmoniídeos e comu- nidades faunísticas da formação Ponta Grossa, Devoniano, no estado do Paraná. Programa de Pós-graduação em Geociências, Universidade Federal do Rio Grande do Sul, Tese de Doutorado, $112 \mathrm{p}$.

Popp, M.T.B.; Coimbra, J.C. \& Hauch, A. 1996. Revisão do gênero Paracalmonia Struve, 1958 (pro Proboloides Clarke, 1913), Trilobita - um ensaio de sistemática filogenética. Gaia, 12:1932.

Quadros, R. 1987. Paleontologia dos Brachiopoda Lingulida, Strophomenida, Spiriferina, Terebratulida - devonianos, da Serra de Atimã e arredores, Mato Grosso, Brasil. Programa de Pós-graduação em Geociências, Universidade Federal do Rio Grande do Sul, Tese de Doutorado, 87 p.

Reed, F.R.C. 1918. Notes on the genus Homalonotus. Geological Magazine, New Series, ser. VI, 5:262 - 327.

Reed, F.R.C. 1925. Revision of the Fauna of the Bokkeveld Beds. Annals of the South African Museum, 22:165-232.

Rehfeld, U. \& Mehl, J. 1989. Andinodesma radiata n. gen. n. sp., a grammysiid taxon from the Lower Devonian Catavi-Formation (Bolivia) and its autoecological and phylogenetic implications. Paläontologische Zeitschrift 63(3/4):263-279.

Renaud, A. 1942. Le Dévonien du synclinorium médian Brest-Laval. Mémoire de la Société Géologique et Minéralogique de Bretagne, 7:1-436.

Richter, R. \& Richter, E. 1932. Unterlagen zum Fossilium Catalogs VI. Senckenbergiana, 14:359-371.

Rodrigues, S.C.; Leme, J.M. \& Simões, M.G. 2003. Tafonomia comparada dos Conulatae (Cnidaria), Formação Ponta Grossa (Devoniano), Bacia do Paraná, Estado do Paraná. Revista Brasileira de Geociências, 4(33):1-10.

Rubinstein, C.; Melo, J.H.G. \& Steemans, P. 2005. Lochkovian (earliest Devonian) miospores from the Solimões Basin, northwestern Brazil. Review of Palaeobotany and Palynology, 133:91-113.

Salter, J.W. 1864. A monograph of the British trilobites from the Cambrian, Silurian and Devonian formations. Part 1. Monograph of the Palaeontographical Society:1-80.

Salter, J.W. 1865. A monograph of the British trilobites from the Cambrian, Silurian and Devonian formations. Part 2. Monograph of the Palaeontographical Society: 1-80.

Sanchez, T.M. \& Benedetto, J.L. 1983. Paleoecologia, comunidades bentonicas y sucesion paleoambiental en el Grupo Rio Cachiri, Devonico, Sierra de Perija, Venezuela. Ameghiniana, 20(3/4):163-198.

Sandford, A.C. 2002. Systematics, biostratigraphy and palaeoenvironments of Echidnops, a new genus of trilobite from the Late Silurian-Early Devonian of south-eastern Australia: Phacopidae of Victoria, Part 1. Memoirs of the Association of Australasian Palaeontologists, 27:1-31.

Sandford, A.C. 2005. Homalonotid trilobites from the Silurian and Lower Devonian of south-eastern Australia and New Zealand (Arthropoda: Trilobita: Homalonotidae). Memoirs of Museum Victoria, 62(1):1-66.

Saul, J. 1965 Trilobita. Antarctic Research Series, 6:241-281.

Saul, J.M. 1967. Burmeisteria (Digonus) accraensis, a new homalonotid trilobite from the Devonian of Ghana. Journal of Paleontology, 41(5):1126-1136.

Saul, J.M.; Boucot, A.J. \& Finks, R.M. 1963. Fauna of the Accraian series (Devonian of Ghana) including a revision of the gastropod Plectonotus. Journal of Paleontology, 37(5):1042-1052.

Simões, M.G.; Mello, L.H.C.; Rodrigues, S.C.; Leme, J.M. \& Marques, A.C. 2000. Conulariid taphonomy as a tool in 
paleoenvironmental analysis. Revista Brasileira de Geociências, 4(30): 757-762.

Simões, M.G.; Leme, J.M.; Rodrigues, S.C. \& Van Iten, H. 2003. Some Middle Paleozoic Conulariids (Cnidaria) as possible example of taphonomic artifacts. Journal of Taphonomy, 1(3): 165-186.

Soares, S.P. 2007. Sistemática, Tafonomia e Paleoecologia de Trilobita Phacopida (Homalonotidae e Calmoniidae), Formação Ponta Grossa (Devoniano), Sub-Bacia Apucarana, Estado do Paraná, Brasil. Programa de Pós-Graduação em Geologia Sedimentar, Universidade de São Paulo, São Paulo, Dissertação de Mestrado, $140 \mathrm{p}$.

Soares, S.P.; Simões, M.G. \& Leme, J.M. 2008. O papel da fossilização e do intemperismo na sistemática dos trilobites Phacopida (Calmoniidae e Homalonotidae), Formação Ponta Grossa, (Devoniano), Bacia do Paraná, Brasil. Revista Brasileira de Paleontologia, 11(2):117-128.

Speyer, S.E. 1987. Comparative taphonomy and palaeoecology of trilobite lagerstätten. Alcheringa, 11:205-232.

Speyer, S.E. 1991. Trilobite taphonomy: a basis for comparative studies of arthropod preservation, functional anatomy and behaviour. In: S.K. Donovan (ed.) The Processes of Fossilization, Belhaven Press, p. 194-219.

Speyer, S.E. \& Brett, C.E. 1986. Trilobite taphonomy and Middle Devonian taphofacies. Palaios, 1(3):312-327.

Struve, W. 1958. Über einige Fälle von Homonymie bei Gattungen der Phacopacea. Senckenbergiana Lethaea, 39: 301-302.

Swinnerton, H.H. 1915. Suggestions for a revised classification of trilobites. Geological Magazine, New Series, 2:407-496;538545.

Thomas, I. 1905. Neue Beiträge zur Kenntniss der devonischen Fauna Argentiniens. Zeitschrift der Deutschen Geologischen Gesellschaft, 57:233-290.
Thomas, A.T. 1977. Classification and phylogheny of Homalonotid trilobites. Palaeontology, 20(1):159-178.

Thomas, A.T. 1979. Trilobite associations in the British Wenlock. In: A.L. Harris; C.H. Holland \& B.E. Leake (eds.) The Caledonides of the British Isles-reviewed. Special Publications of the Geological Society of London 8, p. 447-451.

Tomczykowa, E. 1975a. Homalonotinae in Upper Silurian and Lowermost Devonian biostratigraphy and palaeogeography. Fossils and Strata, 4:409-414.

Tomczykowa, E. 1975b. The Trilobite Subfamily Homalonotinae from the Upper Silurian and Lower Devonian of Poland. Acta Palaeontologica Polonica, 20(1):3-46.

Wenndorf, K.W. 1990. Homalonotinae (Trilobita) aus dem Rheinischen Unter-Devon. Palaeontographica Abteilung A, 211:1-184.

Whittington, H.B. 1993. Morphology, anatomy and habits of the Silurian homalonotid trilobite Trimerus. Memoirs of the Association of Australasian Palaeontologists, 15:69-83.

Whittingon, H.B.; Chatterton, B.D.E.; Speyer, S.E.; Fortey, R.A.; Owens, R.M.; Chang, W.T.; Dean, W.T.; Jell, P.A; Lawrie, J.; Palmer, A.R.; Repina, L.N.; Rushton, A.W.A.; Shergold, J.H.; Clarkson, E.N.K.; Wilmot, N.V. \& Kelly, S.R.A. 1997. Treatise on Invertebrate Paleontology, Pt. O, Arthropoda 1, Trilobita (revised edition). Lawrence, Geological Society of America and The University of Kansas Press, 530 p.

Wolfart, R. 1968. Die Trilobiten aus dem Devon Boliviens und ihre Bedeutung für Stratigraphie und Tiergeographie. Beihefte zum Geologischen Jahrbuch, 74:5-201.

Woodward, H. 1903. On some fossil prawns from the Osborne beds of the Isle of Wight. Geology Magazine, 10(4):97-99.

Zabini, C. 2007. Lingulídeos da sucessão devoniana da Bacia do Paraná, região dos Campos Gerais, Brasil: revisão de conceitos biológicos-ecológicos e análise tafonômica básica. Programa de Pós-graduação em Geociencias, Universidade Federal do Rio Grande do Sul, Dissertação de Mestrado, 130 p.

Received in January, 2009; accepted in March, 2009. 